\title{
Content of rare earth elements in basalt aggregate from Winna Góra, Poland
}

\author{
Marcin LUTYŃSKI ${ }^{*}$, Beata GRYNKIEWICZ-BYLINA ${ }^{2}$, Bożena RAKWIC ${ }^{3}$ \\ and Jacek NOWAK ${ }^{4}$
}

Authors' affiliations and addresses: ${ }^{1}$ Department of Mining, Faculty of Mining, Safety Engineering and Industrial Automation, Silesian University of Technology, Akademicka 2, 44-100 Gliwice, Poland e-mail: marcin.lutynski@polsl.pl

${ }^{2}$ Laboratory of Material Engineering and Environment, ITG KOMAG, Pszczyńska 37, 44-100 Gliwice, Poland e-mail: bbylina@komag.eu

${ }^{3}$ Laboratory of Material Engineering and Environment, ITG KOMAG, Pszczyńska 37, 44-100 Gliwice, Poland

e-mail: brakwic@komag.eu

${ }^{4}$ Department of Applied Geology, Faculty of Mining, Safety Engineering and Industrial Automation, Silesian University of Technology, Akademicka 2, 44-100 Gliwice, Poland e-mail: jacek.nowak@polsl.pl

\section{*Correspondence:}

Marcin Lutyński, Department of Mining, Faculty of Mining, Safety Engineering and Industrial Automation, Silesian University of Technology, Akademicka 2, 44-100 Gliwice, Poland e-mail: marcin.lutynski@polsl.pl

Funding information:

Silesian University of Technology, 06/050/GGW18/0063-01

ITG KOMAG

E/DLS-24820/OR $\div$ OR2

Acknowledgement:

This publication is supported by the Rector's grant in the field of research and development. Silesian University of Technology, grant number 06/050/GGW18/0063-01.

The research of content of REE is funded by research grant ITG KOMAG, grant number E/DLS-24820/OR $\div$ OR2.

\section{How to cite this article:}

Lutyński, M., Grynkiewicz-Bylina, B., Rakwic, B. and Nowak, J. (2021). Content of rare earth elements in basalt aggregate from Winna Góra, Poland. Acta Montanistica Slovaca, Volume 26 (2), 315-326

DOI:

https://doi.org/10.46544/AMS.v26i2.10

\begin{abstract}
Seek for new Rare Earth Elements (REE) sources encourage looking for easily available sources located in Europe. REE in evolved magmatic systems are predominantly associated with alkali environments. Therefore, it was decided to identify the content of REE in alkali igneous rocks of the Winna Góra basalt quarry located in Lower Silesia, Poland. In this study, a commercially available basalt aggregate from Winna Góra deposit located in the south-western part of Poland near Jawornik was examined for REE content. Mineral content and chemical composition were examined with a light microscope, XRD and XRF, whereas trace element content was measured with the ICP-MS technique. A new method of sample preparation for the purpose of REE identification in basalt aggregate based on pressure microwave mineralisation was developed. Mineral composition and TAS diagram classify aggregate as tephrite. The mineral composition of samples reflects typical mafic and ultramafic rocks. Quantitative mineralogical analysis by the Rietveld method showed that the main minerals are anorthite (46.7\%) and augite (37.4\%) with a minor content of forsterite $(7.5 \%)$, nepheline $(7.4 \%)$ and apatite below $1 \%$. The total content of REE does not exceed $132 \mathrm{ppm}$. Chondrite normalised curves show the highest concentration of $\mathrm{La}$ and Pr. In the case of HREE, the majority of elements (Eu, Tb, Dy, Ho, Er, Yb) concentrations were below $1 \mathrm{ppm}$, a Tm and Lu were not detected. The low enrichment in HREE was also reflected in $\mathrm{La} / \mathrm{Gd}$ ratios. Obtained results are comparable to the REE contents in the western part of the Cenozoic European Volcanic Province.
\end{abstract}

\section{Keywords}

basalt aggregate; Rare Earth Elements; chondrite patterns 


\section{Introduction}

The global need for a more efficient, sustainable management of natural resources has been the focus of attention in recent years. This is particularly important given the fact that some of the elements found in nature are crucial for the continuous development of civilisation and technology. Among them are Rare Earth Elements (REE). REE, in accordance with the classification of the International Union of Pure and Applied Chemistry (IUPAC), are a group of seventeen chemical elements in the periodic table, in particular, the fifteen lanthanides as well as yttrium and scandium. All these elements occur in nature but not in a pure state and, in most cases, need advanced processing methods to be extracted. Hence, the need for sustainable extractive methods and/or recovery and recycling of these elements (Likhachev, 2002; Kuric, 2011; Kuric et al., 2019). The problem with REE supply is due to the fact that these elements are never found in an equal or predictable distribution (Gupta and Krishnamurthy, 1992; Sága et al., 2019). There are three minerals abundant in REE that are commercially exploitable; these are bastnäsite, monazite and xenotime. Other sources of REE include ion-adsorbed clays, which are a very important source of heavy rare earth elements where up to $60 \%$ of Rare Earth Oxides (REO) content in these clays comes from yttrium group elements. These clays are easier to process since they require only hydrometallurgical processing (Jordens et al., 2013). Typical beneficiation methods of REE include processes such as gravity separation, magnetic separation, electrostatic separation and froth flotation. Global reserves of REE calculated as the REO equivalent and REE mine production is presented in Table 1. As it can be seen from the table, global mine production was estimated to have increased to 210000 tons of REO equivalent, and it indicates an $11 \%$ increase compared with that of 2018. In the United States, the production of mineral concentrates increased by $44 \%$ compared to 2018. Still, China dominates the global supply of REE, and it also has the largest reserves.

\begin{tabular}{|c|c|c|c|}
\hline & \multicolumn{2}{|c|}{ Mine production $[\mathrm{t}]$} & \multirow[t]{2}{*}{ Reserves [t] } \\
\hline & 2018 & 2019 & \\
\hline United States & 18000 & 26000 & 1400000 \\
\hline Australia & 21000 & 21000 & 3300000 \\
\hline Brazil & 1100 & 1000 & 22000000 \\
\hline Burma (Myanmar) & 19000 & 22000 & N/A \\
\hline Burundi & 630 & 600 & N/A \\
\hline Canada & - & - & 830000 \\
\hline China & 120000 & 132000 & 44000000 \\
\hline Greenland & - & - & 1500000 \\
\hline India & 2900 & 2900 & 6900000 \\
\hline Madagascar & 2000 & 2000 & N/A \\
\hline Russia & 2700 & 2700 & 12000000 \\
\hline South Africa & - & - & 790000 \\
\hline Tanzania & - & - & 890000 \\
\hline Thailand & 1000 & 1000 & N/A \\
\hline Vietnam & 920 & 920 & 22000000 \\
\hline Other Countries & 60 & - & 310000 \\
\hline World total (rounded) & 190000 & 190000 & 120000000 \\
\hline
\end{tabular}

In European Union, the concept of critical raw materials was introduced in 2011 in the communication on raw materials of the European Commission (European Commission, 2011). Since then, two updated lists of critical raw materials have been published - in 2014 and 2017 (European Commission, 2014, 2017). In each list, as a critical raw material, REE were listed with division into Heavy Rare Earth Elements, i.e. Dysprosium, Erbium, Europium, Gadolinium, Holmium, Lutetium, Terbium, Thulium, Ytterbium, Yttrium and Light Earth Elements, i.e. Lanthanum, Cerium, Praseodymium, Neodymium, Samarium. Estimates of McLeod and Shaulis (2018) show that REEs constitute $<0.022 \%$ of the elemental budget of Earth's upper crust but are intricately associated with specific geological environments. They point out that of the 799 REE deposits worldwide (including potential resources) for which REE-mineralogical data is currently available for, 122 are associated with evolved and/or alkaline igneous activity (not including carbonatites, of which there are 149). Alkaline igneous rocks host deposits of a variety of rare metals and industrial rocks and minerals. In most cases, these 
rocks are used as industrial rocks and aggregates. Nevertheless, the potential of alkali igneous rocks as a source for REE has been highlighted in several publications (McLeod and Shaulis, 2018; Dostal, 2017; Goodenough et al., 2016; Lesnov, 2012). In general, REE in evolved magmatic systems are predominantly associated with alkali environments (McLeod and Shaulis, 2018). Therefore, it was decided to identify the content of REE in alkali igneous rocks of the Winna Góra basalt quarry located in Lower Silesia, Poland. Previous studies were focused on the xenoliths occurring in this province rather than host rocks (Dajek et al., 2015). The content of REE in these particular deposits has not been identified. Therefore, it is crucial to verify if these contents are relatively higher than the average abundances of REE in Earth's crust and contents in the Western part of the Cenozoic European Volcanic Province (Tab. 2).

Tab. 2. Average abundance of REE ( $\mathrm{ppm}$ ) in Earth's crust and basanites from Siebengebirge Volcanic Field compared with chondritic abundances.

\begin{tabular}{|c|c|c|c|c|c|}
\hline \multirow[b]{2}{*}{ Elements } & \multicolumn{3}{|c|}{ Abundance in Earth's crust } & \multirow{2}{*}{$\begin{array}{c}\text { Chondritic abundance } \\
\text { Pourmand, Dauphas and } \\
\text { Ireland (2012) }\end{array}$} & \multirow{2}{*}{$\begin{array}{c}\text { Siebengebirge basanites } \\
\text { (Germany) } \\
\text { (Kolb et al. 2012) }\end{array}$} \\
\hline & $\begin{array}{c}\text { Taylor and } \\
\text { McLennan (1985) }\end{array}$ & $\begin{array}{c}\text { Wedepohl } \\
(1995)\end{array}$ & $\begin{array}{c}\text { Lide and } \\
\text { Frederikse (1997) }\end{array}$ & & \\
\hline $\mathrm{La}$ & 16.00 & 30.00 & 39.00 & 0.2469 & 52.40 \\
\hline $\mathrm{Ce}$ & 33.00 & 60.00 & 66.50 & 0.6321 & 100.88 \\
\hline $\operatorname{Pr}$ & 3.90 & 6.70 & 9.20 & 0.0959 & 11.26 \\
\hline $\mathrm{Nd}$ & 16.00 & 27.00 & 41.50 & 0.4854 & 44.26 \\
\hline $\mathrm{Sm}$ & 3.50 & 5.30 & 7.05 & 0.1556 & 8.26 \\
\hline $\mathrm{Eu}$ & 1.10 & 1.30 & 2.00 & 0.0599 & 2.53 \\
\hline Gd & 3.30 & 4.00 & 6.20 & 0.2093 & 7.06 \\
\hline $\mathrm{Tb}$ & 0.60 & 0.65 & 1.20 & 0.0378 & 1.00 \\
\hline Dy & 3.70 & 3.80 & 5.20 & 0.2577 & 5.33 \\
\hline Ho & 0.80 & 0.80 & 1.30 & 0.0554 & 0.96 \\
\hline $\mathrm{Er}$ & 2.20 & 2.10 & 3.50 & 0.1667 & 2.35 \\
\hline $\mathrm{Tm}$ & 0.30 & 0.30 & 0.52 & 0.0261 & 0.31 \\
\hline $\mathrm{Yb}$ & 2.20 & 2.00 & 3.20 & 0.1694 & 1.86 \\
\hline $\mathrm{Lu}$ & 0.30 & 0.35 & 0.80 & 0.0256 & 0.26 \\
\hline $\mathrm{Y}$ & 20.00 & 24.00 & 33.00 & 1.3950 & 24.97 \\
\hline $\mathrm{Sc}$ & 30.00 & 16.00 & 22.00 & 5.4930 & 27.75 \\
\hline Total & 136.90 & 184.30 & 242.17 & 9.5118 & 291.42 \\
\hline
\end{tabular}

As part of this work, common analytical methods used to determine the content of REE in rocks were assessed. The selection was based on suitable detection limit and accuracy of obtained results (Cavalcante et al., 2014; Sindern, 2017; Wengi et al., 2010; Latacz, 2017; Wdowin and Franus, 2014).

The first method that is commonly used for the analysis of rare earth elements (REEs) is X-ray fluorescence spectroscopy (XRF) which is divided into the analysis of minors and traces in materials with natural origin and the analysis of industrial products containing REEs as the main, minor or trace components in solid material (Pauw et al., 2020). The XRF method is considered to be quick and not requiring any additional steps for the preparation of the sample, except the case when the material is powdered and needs to be compressed. However, its significant disadvantage is the high error of determination and a high average lower limit of detection (LLD) of about 1-10 $\mu \mathrm{g} / \mathrm{g}$ (Schramm, 2016). An alternative method is mass spectrometry with an inductive coupling of plasma - ICP-MS, where spectrometric analyses of liquid samples mineralised in inorganic acids are analysed (Seregina, 2018). It is one of the very labour-intensive methods but characterised by higher sensitivity than XRF (Pinto et al., 2012). This method involves a more complex sample preparation process affecting the yield of analysed elements. Sample preparation is a wet open or closed process (Holubcik, M. et al., 2020). The most effective when analysing samples is a closed system, in which the digestion of the sample material is at elevated temperature and pressure. This allows for the reduction of contamination of the sample. Digestion of the sample in a closed system is carried out either by conventional or microwave heating. Microwave heating reduces digestion time which in the case of conventional heating may last up to dozens of hours (Kozak, 2012). Fluids used for the digestion of samples are selected based on the mineral composition of the sample and, in the case of a complex matrix with high content of $\mathrm{SiO}_{2}$, except oxidising $\mathrm{HNO}_{3}$ acid, the silica dissolving acid $\mathrm{HF}$ is necessary (Krishna, 2009). The important parameters of the mineralisation process include temperature, pressure, time and heating power. These parameters depend on the nature of the mineralised matrix and should be selected individually for each tested material based on preliminary tests. Other techniques used to detect REE are LA-ICP-MS analysis, where a pulsed high-energy laser beam is focused on the surface of a solid sample, 
which is placed in an air-tight sample chamber flushed with a carrier gas. Irradiation causes the release of aerosol particles from the sample surface, which are transported to the ICP ion source in which they are vaporised and finally ionised (Sindern, 2017).

The aim of this work was to identify and assess the potential of REE in the commercially developed basalt deposit of Winna Góra near Jawor in Poland with the use of the ICP-MS technique and microwave pressure microwave mineralisation.

\section{Geological setting}

The Winna Góra deposit is located in the South-Western part of Poland in Lower Silesia Voivodeship. Mineral reserves of this deposit are estimated at 11246000 tonnes with an average yearly production of approximately $500000 \mathrm{t}$ (Szuflicki et al., 2019). The tertiary mafic rock deposit belongs to the Polish part of Tertiary-Quaternary Cenozoic European Volcanic Province. The European Cenozoic volcanic province surrounds the Alps from South-West France and expands to Hungary and Czech Republic, with outcrops reaching the South-Western part of Poland (see Fig. 1). Basaltic volcanism in Lower Silesia, at the northern termination and eastern flanks of the Ohre Rift, spanned the Oligocene-Pliocene interval (Birkenmayer et al., 1970). In Lower Silesia, basalts are a common name of various alkaline igneous rocks with an aphanitic structure. The rocks found in these regions are basalt, trachyte, tephrite, basanite, phonolite basanite, quartz latite, foid-bearing basalt, nepheline syenite, dolerite, basanitoid, limburgite, ankarite, trachyandesite, trachyphonolite (Szuflicki et al., 2019).

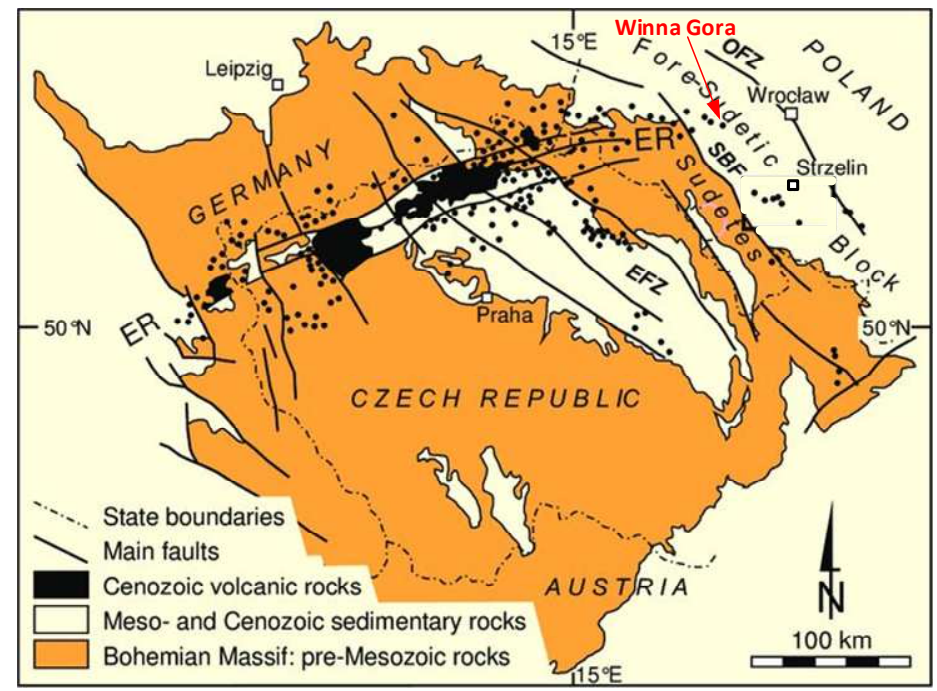

Fig. 1. Geological setting of the Bohemian Massif and the Eger Rift (modified from Awdankiewicz et al., 2016) with the location of the study area - the Winna Góra volcanic rock outcrop. EFZ - Elbe Fault Zone, ER - Eger Rift, OFZ - Odra Fault Zone, SBF - Sudetic Boundary Fault.

\section{Material and Methods}

Rock samples were acquired from an active quarry. The raw material was a fine aggregate of size 0-2 mm. The total mass of samples was $50 \mathrm{~kg}$. Samples were air-dried and quartered in a Jones splitter to obtain analytical samples. The condition of the basalt sample is shown in Fig. 2.

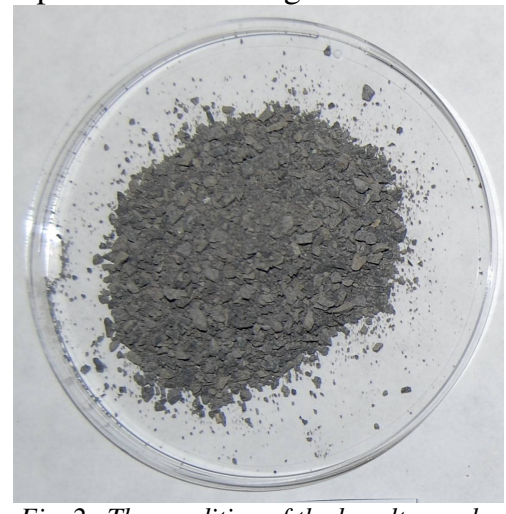

Fig. 2. The condition of the basalt sample. 
In order to properly characterise basalt aggregate and assess REE potential, the following set of analyses was conducted:

- structural - using light microscopy (LM),

- mineral composition-with the use of the X-ray diffraction (XRD) method,

- chemical composition-using the X-ray fluorescence method (XRF),

- trace element analysis with Inductively coupled plasma mass spectrometry (ICP-MS).

$\mathrm{X}$-ray diffraction phase identification was carried out in Empyrian diffractometer manufactured by Panalytical equipped with a copper lamp at $40 \mathrm{kV}$ and amperage of $30 \mathrm{~mA}$. For quantitative phase analyses based on the Rietveld approach, HighScore plus software was used.

ZSX Primus II spectrometer manufactured by Rigaku was used for elemental analysis (from Be to U). The spectrometer uses an X-ray lamp with $\mathrm{Rh}$ anode $4,0 \mathrm{~kW}$ and amperage of $60 \mathrm{kV}$ and SDD detector. Internal reference materials were used for the tests. Phase and chemical analyses were conducted at the Silesian Centre for Education and Interdisciplinary Research in Chorzów (Poland).

REE content analysis using the ICP-MS was carried out in several stages. In the first one, the method was validated in terms of linearity, LOD detection limit and LOQ determination, as well as accuracy, repeatability and reproducibility. Due to the nature of basalt, an important part of REE content analysis was the sample preparation process using mineralisation in the Microwave Reaction System. Pressure microwave mineralisation was chosen as the preferred method due to the chemical composition of samples. In the next stage, in order to increase the recovery of determined REEs, the developed method was optimised in terms of:

- proportions and/or mixtures of acids used for mineralisation,

- changes in the conditions in which mineralisation is carried out, including increasing the temperature,

- elimination of non-spectral matrix interference caused by the presence of dissolved solids and viscosity change by the introduction of sample diluting.

The results of the optimisation of the method allowed to reduce the method's measuring range. The third stage consists of actual sample analysis based on the elaborated procedure. $0.2 \mathrm{~g}$ of each sample was mineralised in a closed system using $6 \mathrm{ml} 65 \% \mathrm{HNO}_{3}$ and $2 \mathrm{ml} 40 \% \mathrm{HF}$ for 70 minutes at the temperature of $240^{\circ} \mathrm{C}$, the pressure of $60 \mathrm{bar}(0.5 \mathrm{bar} / \mathrm{s}$ increment $)$ and $800 \mathrm{~W}$ power. Once mineralisation was completed, the solution was complexed with $12 \mathrm{ml} \mathrm{H}_{3} \mathrm{PO}_{4}$ and topped up with demi water to $25 \mathrm{ml}$ obtaining a clear and transparent solution. After that, REE content was measured in ICP-MS7900 manufactured by Agilent Technologies. Prior to ICP-MS analyses, the spectrometer was calibrated on certified reference materials and two reagent blanks. The calibration curve was prepared for the element concentration range from 0.005 to $1.8 \mathrm{mg} / \mathrm{dm}^{3}$. The calibration coefficient $R$ for REE are given in Table 3, and the calibration curve for $\mathrm{Y}$ is in Fig. 3.

\begin{tabular}{ccc} 
Tab. 3. The values of the calibration coefficient $R$ for REE. \\
\hline Element & Isotope & $\mathrm{R}$ \\
\hline $\mathrm{Sc}$ & 45 & 0.9998 \\
$\mathrm{Y}$ & 89 & 0.9999 \\
$\mathrm{La}$ & 139 & 0.9998 \\
$\mathrm{Ce}$ & 140 & 0.9998 \\
$\mathrm{Pr}$ & 141 & 0.9996 \\
$\mathrm{Nd}$ & 146 & 0.9998 \\
$\mathrm{Sm}$ & 147 & 0.9999 \\
$\mathrm{Eu}$ & 153 & 0.9999 \\
$\mathrm{Gd}$ & 157 & 0.9998 \\
$\mathrm{~Tb}$ & 159 & 0.9998 \\
$\mathrm{Dy}$ & 163 & 0.9998 \\
$\mathrm{Ho}$ & 165 & 0.9998 \\
$\mathrm{Er}$ & 166 & 0.9995 \\
$\mathrm{Tm}$ & 169 & 0.9998 \\
$\mathrm{Yb}$ & 172 & 0.9998 \\
$\mathrm{Lu}$ & 175 & 0.9998
\end{tabular}




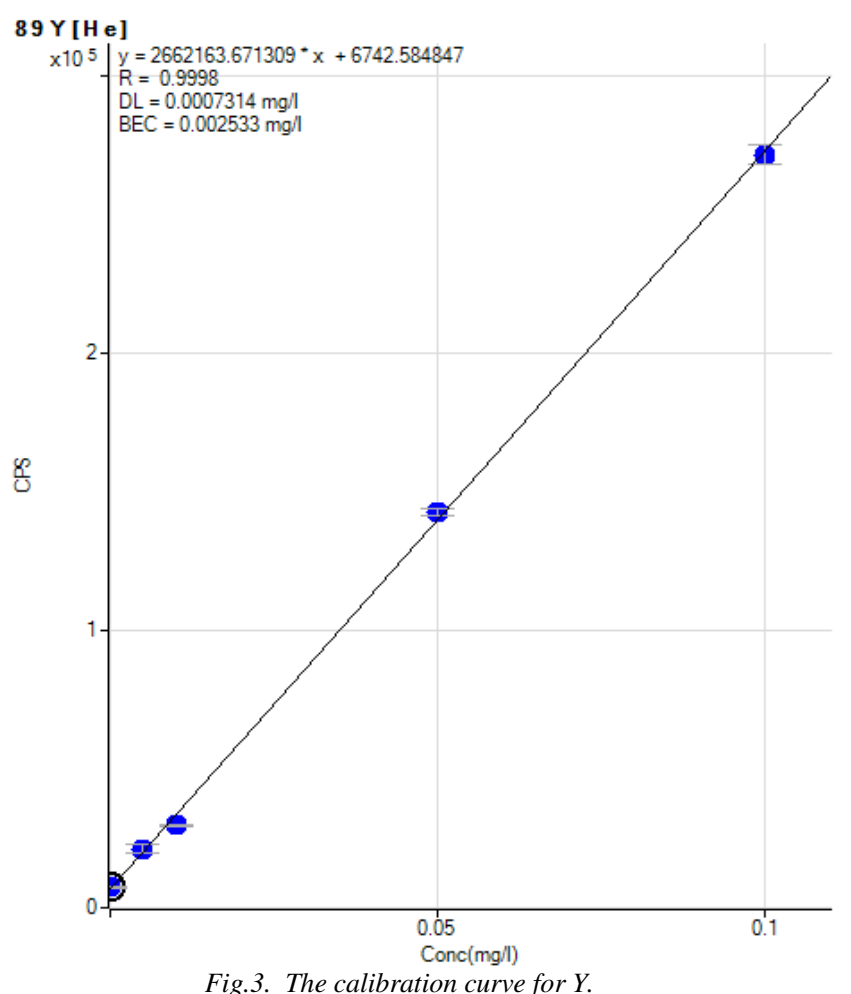

The reagent blank was a mixture of digestion reagents at the concentrations used for sample mineralisation. Trial tests showed that the calibration curves were correct. REE content calculation was conducted with MassHunter 4.4 Workstation Software. Analyses were carried out on five aggregate samples marked as WG/P1-1, WG/P1-2, WG/P1-3, WG/P1-4, WG/P1-5. Each measurement was repeated five times per sample.

\section{Results}

Macroscopic observations using a light stereoscopic microscope show that basalt has a microporhyry structure consisting of olivine, rarely pyroxenes and occasionally plagioclaze. Olivine crystals are often corroded by magma (Fig. 4). Pyroxenes sometimes show zonal or polysynthetic-zonal structure (Fig. 5). Paleocrystals reach a size of up to $2 \mathrm{~mm}$, and in the case of plagioclases, even up to $3 \mathrm{~mm}$. The rock matrix consists of plagioclases, pyroxenes and also opaque minerals, probably magnetite. It should be noted that the arrangement of the plagioclase lamellae clearly indicates a parallel fluidised texture (Fig. 6). Lenticular clusters of pyroxene crystals with a size of up to $0.5 \mathrm{~mm}$ (larger than a rock matrix) are observed.

The rock exhibits slight carbonation, which is manifested by the presence of small clusters of carbonate minerals (probably calcite and dolomite) in the rock matrix and the carbonation of plagioclase, rarely olivine. (Fig. 7)

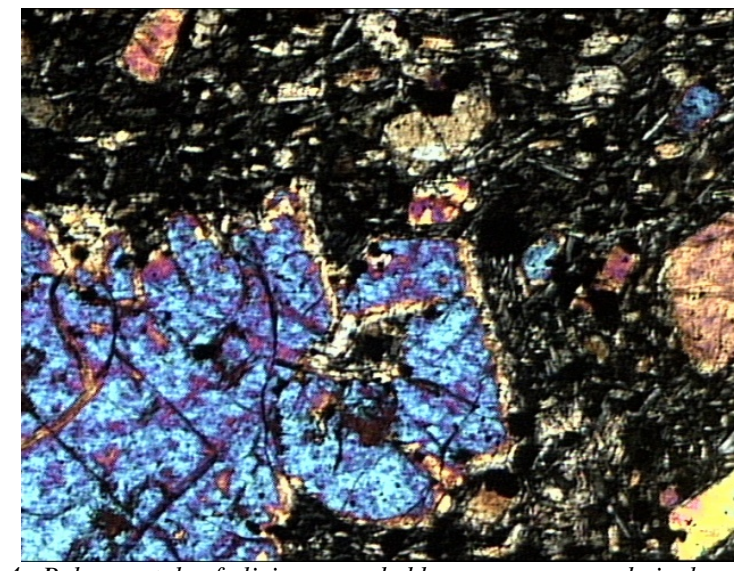

Fig. 4. Paleocrystals of olivine corroded by magma, crossed nicols, magnification $200 x$

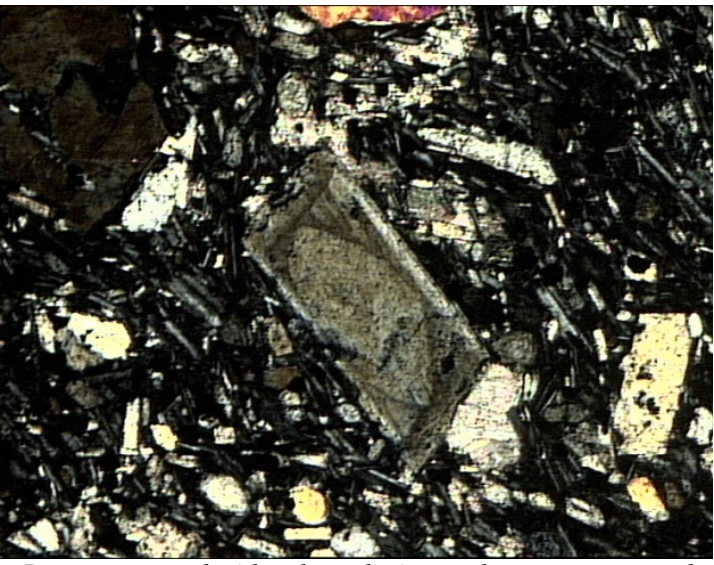

Fig. 5. Pyroxene crystal with polysynthetic-zonal structure, crossed nicols, magnification $200 x$. 


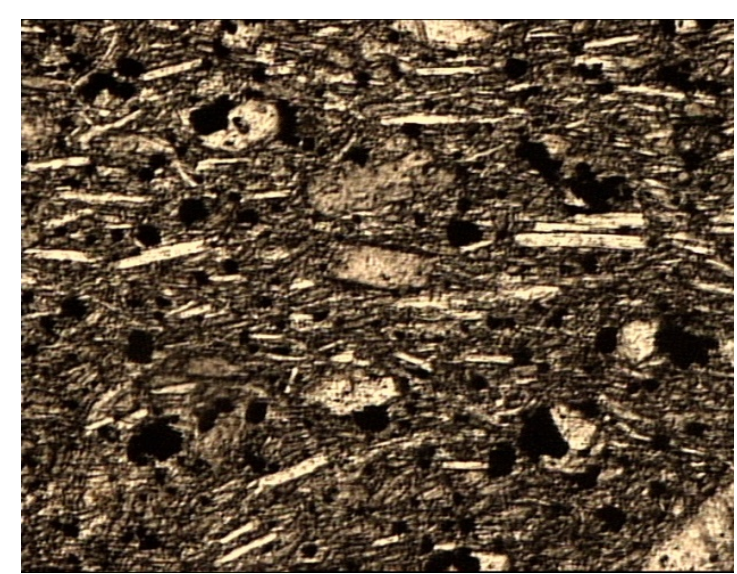

Fig. 6. Parallel arrangement of the plagioclase lamellae indicating fluidised texture, single nicol, magnification 200x.

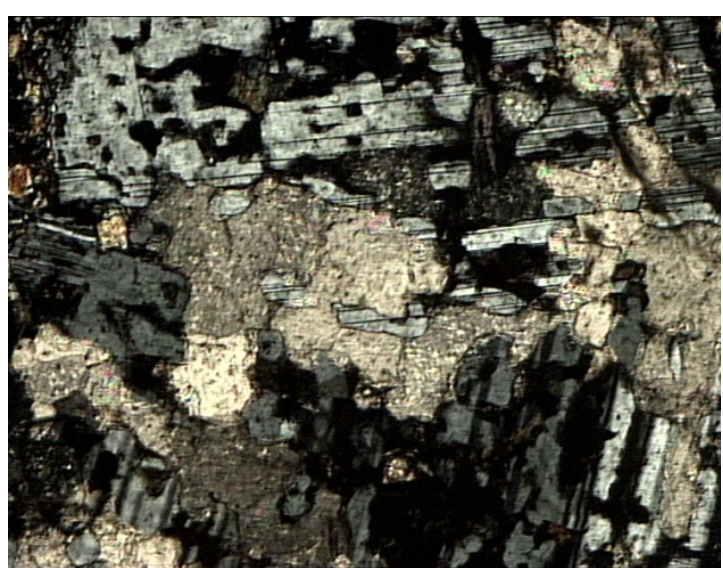

Fig. 7. Plagioclase precrystal carbonation, crossed nicols, magnification $200 x$

Results of phase analysis with X-ray diffraction method revealed peaks of augite, anorthite forsterite, nepheline and apatite (see Fig. 8). Such mineral composition reflects typical mafic and ultramafic rocks. Quantitative mineralogical analysis by the Rietveld method showed that the main minerals are anorthite $(46.7 \%)$ and augite $(37.4 \%)$ with a minor content of forsterite $(7.5 \%)$, nepheline $(7.4 \%)$ and apatite below $1 \%$.

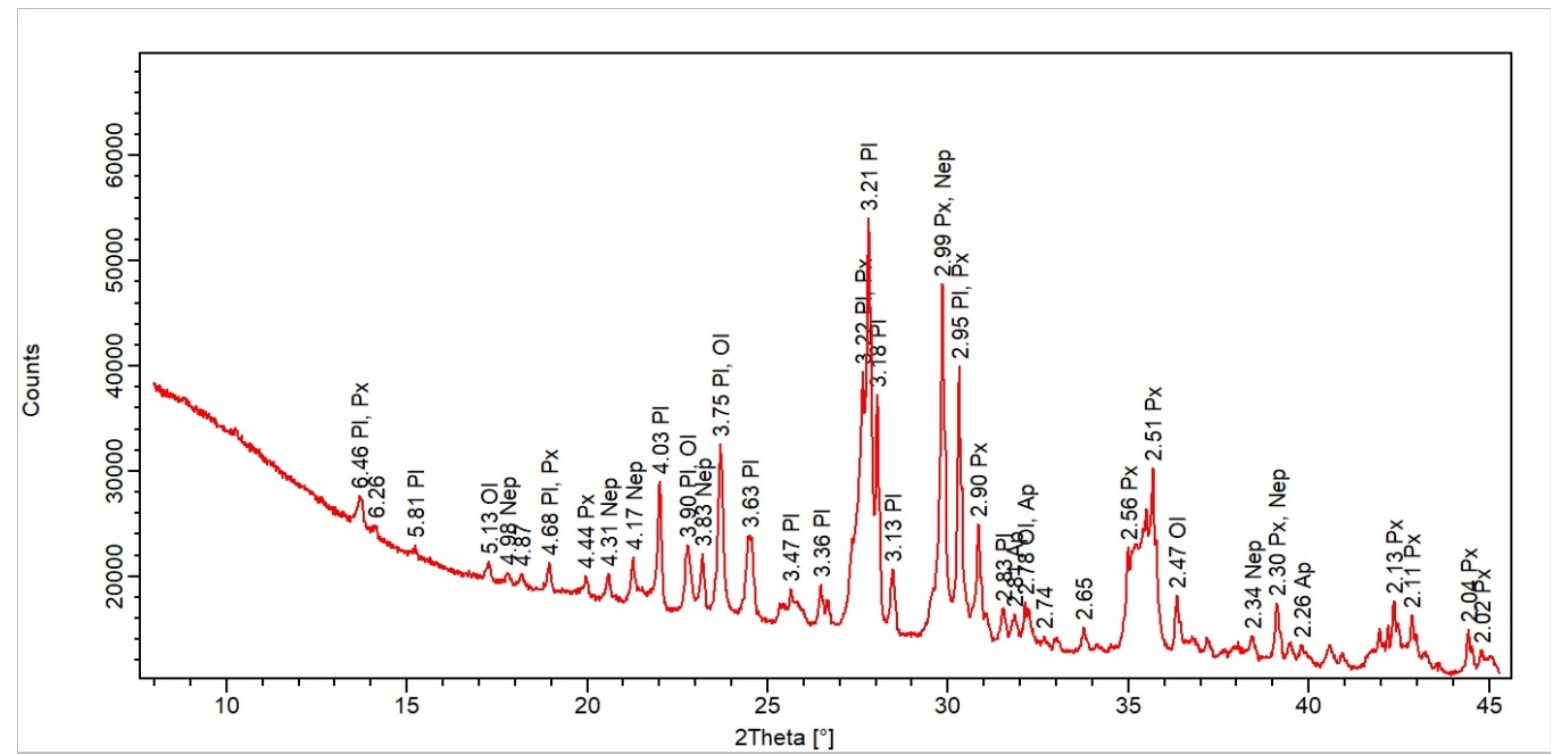

Fig. 8. X-ray diffraction pattern of fine basalt aggregate from Winna Góra. Px-pyroxene, Nep-nepheline, Pl-plagioclaze, Ap - apatite, Ol-olivine.

The chemical composition of basalt aggregate from Winna Góra (Tab. 4) show that the dominant compound is $\mathrm{SiO}_{2}$ (43.54 wt\%). Other compounds with high content are aluminium oxide $\mathrm{Al}_{2} \mathrm{O}_{3}\left(16.27\right.$ wt $\%$ ), iron $\mathrm{Fe}_{2} \mathrm{O}_{3}$ (12.95 wt \%), calcium oxide $\mathrm{CaO}$ (10.25 wt\%), magnesia $\mathrm{MgO}$ (5.93 wt\%) and sodium $\mathrm{Na}_{2} \mathrm{O}$ (4.20 wt $\%$ ). Compounds with lower concentration are titanium oxide $\mathrm{TiO}_{2}(4.2 \mathrm{wt} \%)$ and potassium $\mathrm{K}_{2} \mathrm{O}(1.42 \mathrm{wt} \%)$. Loss on ignition, which incorporates $\mathrm{OH}$ groups and $\mathrm{CO}_{2}$, as expected, are low (1.42 wt \%). The concentration of remaining compounds does not exceed $1 \mathrm{wt} \%$. The chemical composition of basalt aggregate split into compounds with concentration over and below $1 \%$ is shown in Figure 9.

Tab. 4. Chemical composition of basalt aggregate from Winna Góra.

\begin{tabular}{cc} 
Compound & Content [wt\%] \\
\hline $\mathrm{SiO}_{2}$ & 43.54 \\
$\mathrm{TiO}_{2}$ & 2.78 \\
$\mathrm{Al}_{2} \mathrm{O}_{3}$ & 16.27 \\
$\mathrm{Fe}_{2} \mathrm{O}_{3}$ & 12.95 \\
$\mathrm{MnO}$ & 0.25 \\
$\mathrm{MgO}$ & 5.93
\end{tabular}




\begin{tabular}{cc}
$\mathrm{CaO}$ & 10.25 \\
$\mathrm{Na}_{2} \mathrm{O}$ & 4.20 \\
$\mathrm{~K}_{2} \mathrm{O}$ & 1.42 \\
$\mathrm{P}_{2} \mathrm{O}_{5}$ & 0.76 \\
$\mathrm{VO}_{2}$ & 0.03 \\
$\mathrm{Cr}_{2} \mathrm{O}_{3}$ & 0.05 \\
$\mathrm{CoO}$ & 0.01 \\
$\mathrm{NiO}$ & 0.02 \\
$\mathrm{CuO}$ & 0.01 \\
$\mathrm{ZnO}$ & 0.02 \\
$\mathrm{SrO}$ & 0.10 \\
$\mathrm{ZrO}$ & 0.05 \\
$\mathrm{Nb} \mathrm{O}_{5}$ & 0.01 \\
$\mathrm{Cl}$ & 0.10 \\
$\mathrm{LOI}$ & 1.26 \\
$\mathrm{Total}$ & 100.00 \\
\hline
\end{tabular}

Since the concentration of olivine estimated based on the Rietveld method is $7.5 \%$, the TAS classification of igneous rocks (La Maitre et al., 1989) names the basalt aggregate as tephrite (see Fig. 10).
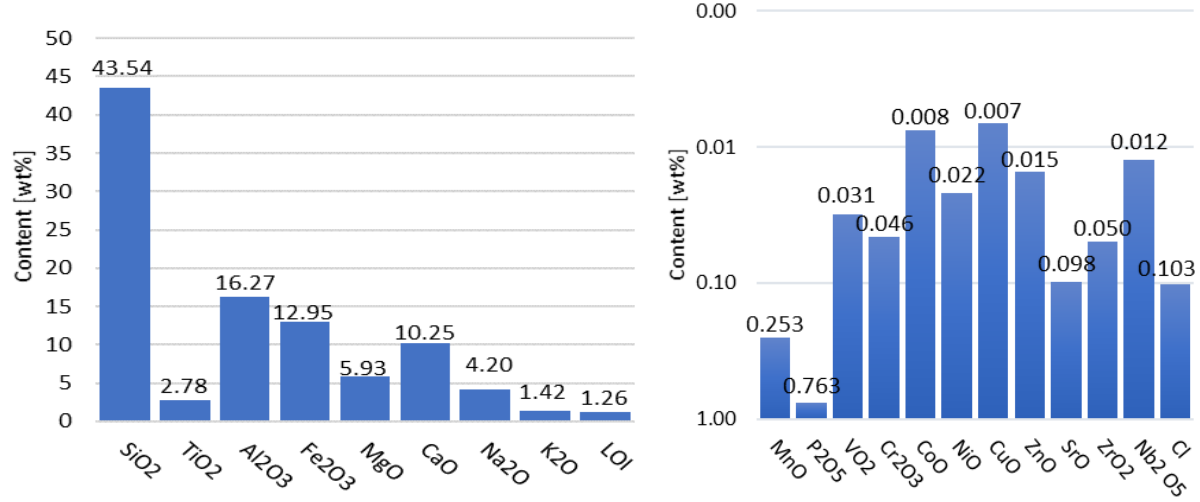

Fig. 9. The chemical composition of basalt aggregate from Winna Góra split into compounds with concentration over(left) and below (right) $1 \%$.

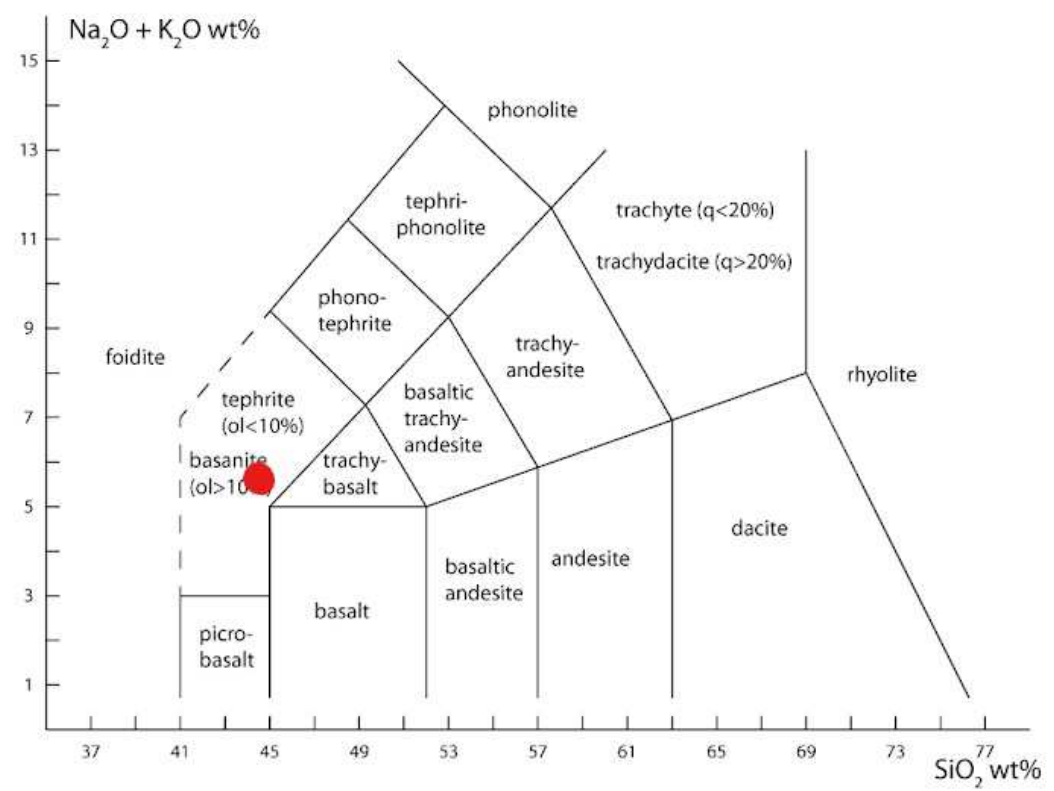

Fig. 10. TAS Diagram with the Winna Góra basalt aggregate marked in red. Olivine is below 10\%; therefore, samples can be classified as tephrite. 
Results of REE abundances measured with ICP-MS are summarised in Table 5. The maximum concentrations do not exceed $50 \mathrm{ppm}$, and the highest concentration can be found for scandium, where in one sample, it reaches $45.6 \mathrm{ppm}$, yet on average, this value does not exceed $27 \mathrm{ppm}$. In the case of yttrium, concentration is even lower, and on average, it does not exceed $15.4 \mathrm{ppm}$ with the maximum concentration of $22.3 \mathrm{ppm}$ in one sample. For lanthanides, the concentrations of Eu, Tb, Dy, Ho, Er, Yb do not exceed $1 \mathrm{ppm}, \mathrm{Tm}$ and Lu do not occur. In the remaining six elements, the highest concentration was found for lanthanum, with the highest concentration of $20.9 \mathrm{ppm}$ in sample WG/P1-1 (11 ppm on average). Cerium concentrations are 22.2 ppm on average, neodymium and samarium concentrations are $13 \mathrm{ppm}$ and $8.1 \mathrm{ppm}$, respectively. Pr concentration does not exceed $10 \mathrm{ppm}$. Gadolinium concentration was low and did not exceed 8.5 ppm. La/Gd normalised ratios show Light REE enrichment over Heavy REE.

Tab. 5. REE abundances (ppm) in basalt aggregate from Winna Góra measured with ICP-MS.

\begin{tabular}{|c|c|c|c|c|c|c|c|c|c|c|}
\hline \multirow{2}{*}{ Element } & \multicolumn{2}{|c|}{ WG/P1-1 } & \multicolumn{2}{|c|}{ WG/P1-2 } & \multicolumn{2}{|c|}{ WG/P1-3 } & \multicolumn{2}{|c|}{ WG/P1-4 } & \multicolumn{2}{|c|}{ WG/P1-5 } \\
\hline & $\mathrm{x}_{\mathrm{a}}$ & $\mathrm{s}_{\mathrm{x}}$ & $\mathrm{x}_{\mathrm{a}}$ & $\mathrm{s}_{\mathrm{x}}$ & $\mathrm{x}_{\mathrm{a}}$ & $\mathrm{s}_{\mathrm{x}}$ & $\mathrm{x}_{\mathrm{a}}$ & $\mathrm{s}_{\mathrm{x}}$ & $\mathrm{x}_{\mathrm{a}}$ & $\mathrm{s}_{\mathrm{x}}$ \\
\hline $\mathrm{Sc}$ & 24.00 & \pm 0.81 & 17.85 & \pm 0.64 & 20.95 & \pm 1.20 & 23.55 & \pm 1.77 & 45.60 & \pm 0.42 \\
\hline $\mathrm{Y}$ & 10.30 & \pm 0.44 & 8.84 & \pm 0.27 & 18.62 & \pm 0.86 & 22.27 & \pm 0.64 & 17.02 & \pm 0.62 \\
\hline $\mathrm{La}$ & 20.91 & \pm 0.31 & 12.80 & \pm 0.42 & 7.02 & \pm 0.56 & 6.34 & \pm 0.36 & 7.85 & \pm 0.51 \\
\hline $\mathrm{Ce}$ & 19.14 & \pm 3.26 & 12.71 & \pm 1.42 & 28.11 & \pm 0.72 & 24.41 & \pm 0.95 & 26.82 & \pm 1.12 \\
\hline $\operatorname{Pr}$ & - & - & 9.72 & \pm 0.68 & 7.55 & \pm 1.37 & 6.28 & \pm 0.69 & 8.14 & \pm 1.37 \\
\hline $\mathrm{Nd}$ & 21.66 & \pm 2.21 & 14.70 & \pm 0.28 & 13.55 & \pm 0.49 & 6.62 & \pm 0.59 & 8.20 & \pm 0.57 \\
\hline $\mathrm{Sm}$ & 8.41 & \pm 0.33 & 8.30 & \pm 2.55 & 7.65 & \pm 0.21 & 6.55 & \pm 0.49 & 9.45 & \pm 0.92 \\
\hline $\mathrm{Eu}$ & - & - & 0.25 & \pm 0.03 & 0.22 & \pm 0.03 & 0.21 & \pm 0.03 & 0.30 & \pm 0.02 \\
\hline Gd & 8.11 & \pm 0.52 & 8.45 & \pm 1.34 & 7.00 & \pm 0.14 & 5.60 & \pm 0.42 & 7.05 & \pm 1.06 \\
\hline $\mathrm{Tb}$ & - & - & 0.22 & \pm 0.01 & 0.02 & \pm 0.01 & 0.02 & \pm 0.01 & 0.02 & \pm 0.01 \\
\hline Dy & 0.11 & \pm 0.01 & 0.73 & \pm 0.01 & 0.74 & \pm 0.02 & 0.62 & \pm 0.04 & 0.64 & \pm 0.05 \\
\hline Ho & - & - & 0.02 & \pm 0.01 & 0.03 & \pm 0.01 & 0.02 & \pm 0.01 & - & - \\
\hline $\mathrm{Er}$ & - & - & 0.19 & \pm 0.01 & 0.22 & \pm 0.01 & 0.16 & \pm 0.02 & 0.14 & \pm 0.01 \\
\hline $\mathrm{Tm}$ & - & - & - & - & - & - & - & - & - & - \\
\hline $\mathrm{Yb}$ & - & - & 0.07 & \pm 0.02 & 0.09 & \pm 0.01 & 0.06 & \pm 0.02 & 0.02 & \pm 0.01 \\
\hline $\mathrm{Lu}$ & - & - & - & - & - & - & - & - & - & - \\
\hline$(\mathrm{La} / \mathrm{Gd})_{\mathrm{N}}$ & 2.19 & & 1.28 & & 0.85 & & 0.95 & & 0.94 & \\
\hline$\Sigma$ REE & 112.64 & & 94.85 & & 111.77 & & 102.09 & & 131.25 & \\
\hline
\end{tabular}

$\mathrm{x}_{\mathrm{a}}$ - average

$\mathrm{s}_{\mathrm{x}}-$ standard deviation

Chondrite normalised patterns for five REE with the highest abundances (Y, La, Ce, Nd, Sm, Gd and Pr) of the basalt aggregate are shown in Fig. 11. La varies from 25 to $85 \mathrm{ppm}, \mathrm{Y}$ is on average $15.4 \mathrm{ppm}$, whereas for $\mathrm{Ce}, \mathrm{Nd}$ and $\mathrm{Gd}$, the values are on average $22.2 \mathrm{ppm}, 13 \mathrm{ppm}$ and $8.1 \mathrm{ppm}$, respectively. Pr normalised concentration is relatively high, with $82.6 \mathrm{ppm}$ on average.

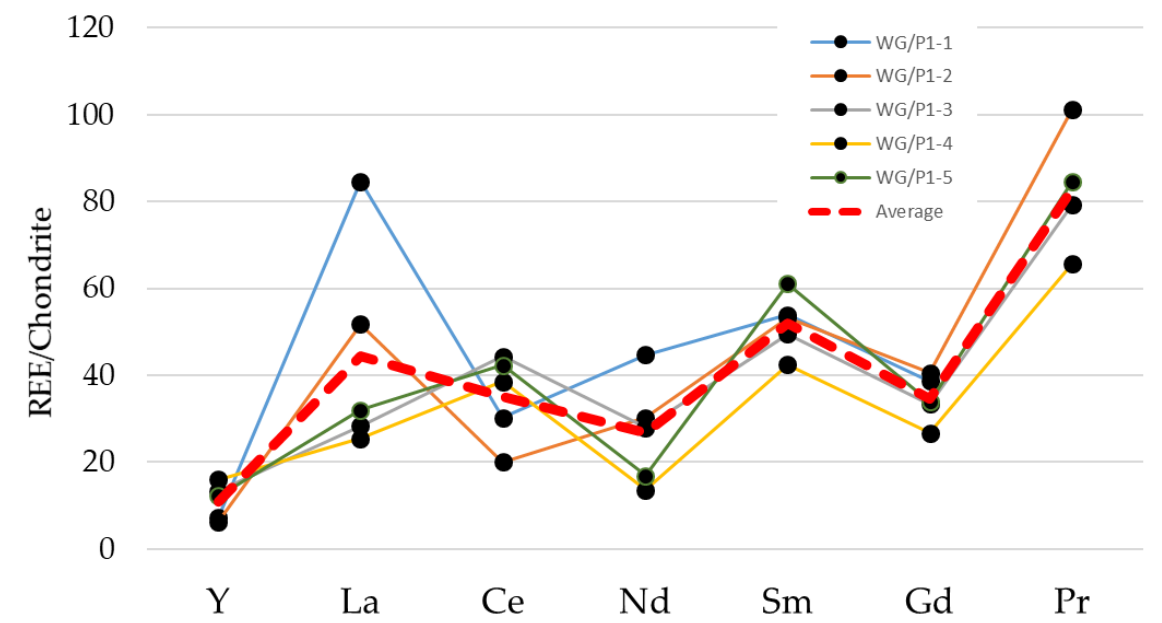

Fig. 11. Chondrite-normalized (Pourmand et al., 2012) rare earth element (REE) patterns for Winna Góra basalt aggregate. 


\section{Discussion and conclusions}

A basalt aggregate from Winna Góra deposit in Poland was examined in terms of chemical composition and REE content (Akatov et al., 2019). The purpose of this work was to verify if REE contents are of any importance when compared to the Western part of the Cenozoic European Volcanic Province (Pástor et al., 2020). Mineral composition and TAS diagram classify aggregate as tephrite. Five samples were tested to estimate REE potential of the basalt aggregate with the use of the ICP-MS method (Kuric, 2011). The total content of REE is $132 \mathrm{ppm}$ and $111 \mathrm{ppm}$ on average. Chondrite normalised curves show the highest concentration of La and Pr. In the case of HREE, the majority of elements (Eu, Tb, Dy, Ho, Er, Yb) concentrations were below $1 \mathrm{ppm}$, a Tm and Lu were not detected. Tm and Lu have very low concentrations, which are much below the ones found in Earth's crust and in the Western part of the Cenozoic European Volcanic Province (Kolb et al., 2012; Taylor and McLennan, 1985; Wedepohl, 1995; Lide and Frederikse, 1997; Pourmand et al., 2012). The low enrichment in HREE was also reflected in La/Gd ratios. In general, results are comparable to the REE contents in the western part of the Cenozoic European Volcanic Province (Kolb et al., 2012; Taylor and McLennan, 1985). This indicates its considerably low commercial potential in comparison to typical REE-bearing minerals such as bastnesite, monazite, and xenotime, which are the main rare earth minerals of commercial importance (Xie et al., 2014). On the other hand, the low content of REE and high content of metal oxides could be an advantage in agricultural use, and rock dust from Winna Góra basalt processing could be used for these purposes (Nunes et al., 2014; Dalmora et al., 2016; Ramos et al., 2017).

Accuracy of obtained results shows that the analytical method developed and employed to assess the REE content in basalt aggregate based on pressure microwave mineralisation can be successfully applied to other complex matrices with high silica content.

\section{References}

Akatov, N., Klačková, I., Mingaleva, Z., Galieva, G., Shaidurova, N. (2019). Expert technology for risk management in the implementation of QRM in a high-tech industrial enterprise, Management Systems in Production Engineering, 27, p.p. 250-254.

Awdankiewicz, M., Rapprich, V. and Míková, J. (2016). Magmatic evolution of compositionally heterogeneous monogenetic Cenozoic Strzelin Volcanic Field (Fore-Sudetic Block, SW Poland). J. Geosci. 425-450, doi:10.3190/jgeosci.221.

Birkenmayer, K., Jerzmañski, J. and Nairn, A.E.M. (1970). Paleomagnetic Studies of Polish Rocks, in Cenozoic Basalts of Lower Silesia. Anal Soc Géolog Pol. 90, 31-61.

Dajek, M., Matusiak-Małek, M., Puziewicz, J. and Ntaflos, T. (2015). Petrology and geochemistry of mafic and ultramafic cumulates occurring as xenoliths in volcanic rocks from Polish part of Central European Volcanic Province.

Dalmora, A.C., Ramos, C.G., Querol, X., Kautzmann, R.M., Oliveira, M.L., Taffarel, S.R., Moreno, T. and Silva, L.F. (2016). Nanoparticulate mineral matter from basalt dust wastes. Chemosphere 144, 20132017.

European Commission (2011). Communication from the Commission to the European Parliament, the Council, the European Economic and Social Committee and the Committee of the Regions tackling the challenges in commodity markets and on raw materials.

European Commission (2014). Communication from the Commission to the European Parliament, the Council, the European Economic and Social Committee and the Committee of the Regions on the review of the list of critical raw materials for the EU and the implementation of the Raw Materials Initiative.

European Commission (2017). Communication from the Commission to the European Parliament, the Council, the European Economic and Social Committee and the Committee of the Regions on the 2017 list of Critical Raw Materials for the EU.

Cavalcante, F., Belviso, C., Piccarreta, G., Fiore, S. (2014): Grain-Size Control on the Rare Earth ElementsDistribution in the Late Diagenesis of Cretaceous Shales from the Southern Apennines (Italy), Journal of ChemistryVolume 2014, Article ID 841747, 11 p., shttp://dx.doi.org/10.1155/2014/841747

De Pauw, E., Tack, P., Lindner, M., Ashauer, A., Garrevoet, J., Vekemans, B., Falkenberg, G., Brenker, F.E., Vincze, L., (2020). Highly Sensitive Nondestructive Rare Earth Element Detection by Means of Wavelength-Dispersive X-ray Fluorescence Spectroscopy Enabled by an Energy Dispersive pn-ChargeCoupled-Device Detector. Anal Chem. 92(1):1106-1113, doi: 10.1021/acs.analchem.9b04176

Dostal, J. (2017). Rare Earth Element Deposits of Alkaline Igneous Rocks, Resources 6, 34, doi:10.3390/resources6030034.

Goodenough, K.M., Schilling, J., Jonsson, E., Kalvig, P., Charles, N., Tuduri, J., Deady, E.A., Sadeghi, M., Schiellerup, H., Müller, A., et al. (2016). Europe's rare earth element resource potential: An overview of 
REE metallogenetic provinces and their geodynamic setting. Ore Geol. Rev. 72, 838-856, Doi:10.1016/j.oregeorev.2015.09.019.

Gupta C.K., Krishnamurthy N. (1992) Extractive metallurgy of rare earths. International Materials Reviews. Vol. 37 (1). doi.org/10.1179/imr.1992.37.1.197

Holubčík, M., Klačková, I., Durčanský, P. (2020) Pyrolysis Conversion of Polymer Wastes to Noble Fuels in Conditions of the Slovak Republic, In Journal Energies 2020, Volume 13, Issue 18, article number 4849.

Jordens A., Cheng Y. P., Waters K.E. (2013) A review of the beneficiation of rare earth element bearing minerals. Minerals Engineering 41, 97-114. https://doi.org/10.1016/j.mineng.2012.10.017

Kolb, M., Paulick, H., Kirchenbaur, M. and Münker, C. (2012). Petrogenesis of Mafic to Felsic Lavas from the Oligocene Siebengebirge Volcanic Field (Germany): Implications for the Origin of Intracontinental Volcanism in Central Europe. J. Petrol 53: 2349-2379, doi:10.1093/petrology/egs053.

Kozak, M. (2012): The application of a microwave reactor for the digestion of solid samples with hydrocarbon matrix, Nafta-Gaz, R. 68, $n r$ 11, 859-867, http://archiwum.inig.pl/INST/nafta-gaz/nafta-gaz/Nafta-Gaz2012-11-12.pdf (in Polish)

Krishna, A., K., Mohan, K. R., Murthy N., N. (2009) Determination of Heavy Metals in Soil, Sediment, and Rock by Inductively Coupled Plasma Optical Emission Spectrometry: Microwave-Assisted Acid Digestion Versus Open Acid Digestion Technique, Atomic Spectroscopy 30(3), pp. 75-81

Kuric, I. (2011). New methods and trends in product development and planning. 1st International Conference on Quality and Innovation in Engineering and Management (QIEM). Cluj Na-poca, 17.3.-19.3. 2011, p.p. 453-456, ISBN:978-973-662-614-2

Kuric, I., Cisar, M., Tlach, V., et al. (2019). Technical Diagnostics at the Department of Automation and Production Systems. Book Series: Advances in Intelligent Systems and Computing, vol. 835, p.p. 474-484.

Likhachev, V. L. (2002). Elektrodvigateli asinkhronnyye. SOLON-R, Moskva. ISBN 5-93455-127-2.

La Maitre, R.W., Bateman, P., Dudek, A., Keller, J., Le Bas, M., Sabine, P., Schmid, R., Sorensen, H., Strckeisen, A. and Wooley, A. (1989). A Classification of Igneous Rocks and Glossary of Terms. Recommendation of the International Union of Geological Science Subcommission on the Systematic of Igneous Rocks; Blackwell Scientific Publications.

Latacz, A., (2017): Determination of rare earth elements in coals and ashes, Prace Instytutu Metalurgii Żelaza 69 (4), 44-47, https://www.imz.pl/files/1519/Latacz\%20s\%2044-47.pdf (in Polish)

Lesnov, F.P. (2012). Rare Earth Elements in Ultramafic and Mafic Rocks and their Minerals. Minor and Accessory Minerals. CRC Press, ISBN 978-0-203-11967-9.

Lide, D.R. and Frederikse, H.P.R. (1997). CRC Handbook of Chemistry and Physics 1997-1998. Chem. Rubber Co. 78.

McLeod, C.L. and Shaulis, B.J. (2018). Rare Earth Elements in Planetary Crusts: Insights from Chemically Evolved Igneous Suites on Earth and the Moon. Minerals 8, 455, Doi:10.3390/min8100455.

Nunes, J.M.G., Kautzmann, R.M. and Oliveira, C. (2014). Evaluation of the natural fertilizing potential of basalt dust wastes from the mining district of Nova Prata (Brazil). J. Clean. Prod. 84, 649-656.

Pástor, M., Živčák, J., Puškár, M., Lengvarský, P., Klačková, I. (2020) Application of Advanced Measuring Methods for Identification of Stresses and Deformations of Automotive Structures, In Journal; Applied Sciences, vol. 10 (21), article number 7510, MDPI, ISSN 2076-3417.

Pinto, F.G., Escalfoni Junior, R., Dillenburg Saint'Pierre, T. (2012). Sample Preparation for Determination of Rare Earth Elements in Geological Samples by ICP-MS: A Critical Review.Analytical Letters, 45:12, 1537-1556, DOI: 10.1080/00032719.2012.677778

Pourmand, A., Dauphas, N. and Ireland, T.J. (2012). A novel extraction chromatography and MC-ICP-MS technique for rapid analysis of REE, Sc and Y: Revising CI-chondrite and Post-Archean Australian Shale (PAAS) abundances. Chem. Geol. 291: 38-54, Doi:10.1016/j.chemgeo.2011.08.011.

Ramos, C.G., Querol, X., Dalmora, A.C., De Jesus Pires, K.C., Schneider, I.A.H., Oliveira, L.F.S. and Kautzmann, R.M. (2017). Evaluation of the potential of volcanic rock waste from southern Brazil as a natural soil fertilizer. J. Clean. Prod. 142, 2700-2706.

Sága, M., Vaško, M., Handrik, M., Kopas, P. (2019). Contribution to random vibration numerical simulation and optimisation of nonlinear mechanical systems, Scientific journal of Silesian University of Technology - Series Transport 103, p.p. 143-154.

Schramm, R. (2016). Use of X-ray Fluorescence Analysis for the Determination of Rare Earth Elements. Physical Sciences Reviews, Volume 1, Issue 9, 20160061, eISSN 2365-659X, ISSN 2365-6581, DOI: https://doi.org/10.1515/psr-2016-0061

Seregina, I.F., Volkov, A.I., Ossipov, K., Bolshov, M.A.(2018) Characterization of REE-Nb ores by a combination of spectrochemical techniques, Spectrochimica Acta Part B: Atomic Spectroscopy, Volume 148, Pages 172-182, https://doi.org/10.1016/j.sab.2018.06.018

Sindern, S. (2017). Analysis of Rare Earth Elements in Rock and Mineral Samples by ICP-MS and LA-ICP-MS, Physical Sciences Reviews, Volume 2: Issue 2, https://doi.org/10.1515/psr-2016-0066 
Szuflicki, M., Malon, A. and Tymiński, M. (2019). Bilans zasobów złóż kopalin w Polsce wg stanu na 31 XII $2018 r$. Państw. Inst. Geol. Inst. Badaw. Warszawa (in Polish).

Taylor, S.R. and McLennan, S.M. (1985). The continental crust: its composition and evolution.

United States Geological Survey (2020). Rare Earths Data Sheet - Mineral Commodity Summaries 2020. https://pubs.usgs.gov/periodicals/mcs2020/mcs2020-rare-earths.pdf.

Wedepohl K.H. (1995). The composition of the continental crust. Geochim. Cosmochim. Acta 59: 1217-1232

Wdowin, M. , Franus, M. (2014): Analysis of fly ash for obtaining rare earth elements, Energy Policy Journal T.17 Z.3, 369-380, http://yadda.icm.edu.pl/baztech/element/bwmeta1.element.baztech-2777a3c0-67664bbd-ae8e-5b36235238f8?q=bwmeta1.element.baztech-0c9bb5cb-317f-42dc-bae8c74c02c69dbb;28\&qt=CHILDREN-STATELESS (in Polish)

WU, W., XU, T., HAO, Q., WANG, Q., ZHANG, S., ZHAO, C. (2010). Applications of X-ray fluorescence analysis of rare earths in China. Journal of Rare Earths Volume 28, Supplement 1: 30-36, ISSN 10020721, https://doi.org/10.1016/S1002-0721(10)60353-5

Xie, F., Zhang, A.T., Dreisinger, D. and Doyle, F. (2014). A critical review on solvent extraction of rare earths from aqueous solutions. Minerals Engineering 56, 10-28. doi.org/10.1016/j.mineng.2013.10.021

Krishna, A., K., Mohan, K. R., Murthy N., N. (2009): Determination of Heavy Metals in Soil, Sediment, and Rock by Inductively Coupled Plasma Optical Emission Spectrometry: Microwave-Assisted Acid Digestion Versus Open Acid Digestion Technique, Atomic Spectroscopy 30(3):75-81, https://www.researchgate.net/publication/233782298_Determination_of_Heavy_Metals_in_Soil_Sedime nt_and_Rock_by_Inductively_Coupled_Plasma_Optical_Emission_Spectrometry_MicrowaveAssisted_Acid_Digestion_Versus_Open_Acid_Digestion_Technique 